\title{
DEVELOPERSKÉ PROJEKTY NA BROWNFIELDS: P̌̌ÍPADOVÉ STUDIE Z BRNA
}

\author{
Ing. Alena MALACHOVÁ \\ RNDR. JOSEF KUNC, PH.D. \\ Katedra regionální ekonomie a správy $\mid$ Depart. of Regional Economics and Administration \\ Ekonomicko-správní fakulta Faculty of Economics and Administration \\ Masarykova univerzita Masaryk university \\ $\triangle$ Lipová 41a, 60200 Brno, Czech Republic \\ E-mail:321861@mail.muni.cz;kunc@econ.muni.cz
}

\begin{abstract}
Anotace
Předevšim více než dvousetleté průmyslové tradice a útlum výroby v poslednich desetiletich jsou př́činou postupného vzniku a koncentrace lokalit brownfields v městě Brně. Opuštěné a zanedbané objekty a prostory se stávaji terčem kritiky ze strany místnich obyvatel, palčivost problému si stále více uvědomuje brněnská radnice, roste i zájem developerů o vybrané lokality. Veřejný $i$ soukromý sektor začinaji nacházet společnou řeč ve snaze o regeneraci brownfields, řada projektů byla úspěšná a mohla by být přikladem pro jiná města $v$ České republice, dalši projekty jsou ve fázi príprav. Předložený přispěvek představuje aktuálni situaci v problematice developerských projektů na brownfields $v$ Brně, jež jsou financovány $z$ veřejných i privátnich zdrojü. Vybrané zásadní projekty jsou podrobněji prezentovány v podobě př́padových studii (pasportů).
\end{abstract}

\section{Klíčová slova}

developerské projekty, brownfields, prípadové studie, Brno, Česká republika

\section{Annotation}

Gradual origination and concentration of brownfield locations in Brno has been caused by the industrial tradition spanning over 200 years and the manufacturing decline in the past decades. The derelict and neglected buildings and spaces have been criticized by the local population, the seriousness of the problem has been acknowledged by the Brno City Hall and we have witnessed increased developer interest in selected locations. Both public and private sectors have found common interest in the brownfields regeneration; many projects have been successful and these projects could be used as examples for other Czech cities; additional projects are in preparation stages. The article presented below describes the current situation in the field of brownfield development projects in Brno - projects financed both from public and private sources. Selected fundamental projects are described in detail in the form of case studies (passports).

\section{Key words}

development projects, brownfields, case studies, Brno city, the Czech Republic

JEL classification: $R 33, R 38, R 58$

\section{Úvod}

Průmyslová historie Brna s tradicí $\mathrm{v}$ textilním a potravinářském průmyslu a později $\mathrm{v}$ chemii, elektrotechnice a strojírenství je dostatečně známá (např. Mareš, 1988; Toušek, Mulíček, 2003; Mulíček, Toušek, 2004; Kunc, Tonev 2008 a další). Podobně jako v dalších průmyslových městech 
Evropy, které prošly vývojovými stádii utváření měst, se nejsilnějším odkazem, který skutečně formoval městské struktury, stal právě odkaz průmyslové výroby. Ta se přirozeně koncentrovala $\mathrm{v}$ prstenci kolem historických jader a postupně s sebou nesla vznik opuštěných a nevyužívaných lokalit, často s ekologickým rizikem, které obyvatelé měst i místní samospráva poměrně citlivě vnímají (Litt et al., 2002; De Sousa, 2006; Kunc et al., 2011a).

V České republice je $\mathrm{z}$ funkčně prostorového pohledu problematika brownfields $\mathrm{v}$ intraurbánním prostředí poměrně frekventovanou a diskutovanou, i když pozornost je primárně upřena na města větší velikosti. V př́ispěvku prezentované Brno zastupují např. studie Steinführer (2006), Kunce a Toneva (2008), Kunce a kol. (2011a), Hlavní město Prahu reprezentují Sýkorová (2007) či Ilík, Ouředníček (2007), na Ostravu se specializuje Vojvodíková (2005, s kolektivem autoru 2011) či Hruška-Tvrdý, Kukuliač a kol. (2011). Pokus o komparace dvou městských prostředí lze nalézt v př́ípadě Brna a Lipska u Steinführer (2006), Brna a Ostravy u Kunce a kol. (2011a) či Krejčího a kol. (2011), přičemž autoři neopomíjejí sledovat i hlubší sociodemografické souvislosti přeměn urbánních struktur, jež měly a stále mají vliv na utváření lokalit brownfields a jejich vnímání rezidenty i místní samosprávou (viz také Klusáček a kol. 2009, 2011).

Nejen zastupitelé místní samosprávy, ale stále častěji i investoři a developeři mají zájem na revitalizaci opuštěných a zanedbaných lokalit (Collier a kol. 2008; Kunc a kol., 2011b; Foral, Andráško, 2012). Přestože má často veřejný a privátní sektor $\mathrm{k}$ regeneraci brownfields odlišný důvod a zájem, výsledek pro město samotné a jeho obyvatele je $\mathrm{v}$ př́ípadě kvalitního projektu pozitivní. Odkud pocházejí finanční prostředky není $\mathrm{v}$ tomto př́ípadě rozhodující a vliv na hospodářský rozvoj nejen města, ale i širšího regionu je hmatatelný (Viturka, 2011; Winklerová, 2011). Cílem př́íspěvku je představit aktuální situaci v realizaci developerských projektů na brownfields financovaných jak veřejným, tak soukromým sektorem. Vybrané důležité projekty jsou představeny podrobněji jako př́padové studie.

\section{Nejvýznamnější developerské projekty v Brně}

Jedním z typů rozvojových zón, o které mají developeři stále větší zájem, jsou brownfields. Podpora regenerace brownfields se stává jednou z priorit pro městské instituce, nebot' znovuoživené lokality, zejména ve vnitřním městě, podporují dynamiku pulzujícího městského organismu. Jejich nevýhodou je poměrně častá kontaminace a finanční náročnost na revitalizaci, dobudování technické a dopravní infrastruktury apod. Tyto skutečnosti mohou být důvodem, proč se investoři raději rozhodnou pro stavby na zelené louce. Přes komplikace s revitalizací představují brownfields př́ležitost, mají velký potenciál. V současné době má město Brno značně omezený rozsah disponibilních ploch pro výstavby a projekty na zelené louce (a nebude tomu lépe), a proto je $\mathrm{v}$ jeho zájmu prezentovat a nabízet investorům či developerům $\mathrm{k}$ nové výstavbě právě lokality brownfields.

Tab. 1: Významné developerské projekty s rozhodujícím majetkovým podílem města Brna

\begin{tabular}{|l|l|c|l|l|}
\hline \multicolumn{1}{|c|}{ Název } & \multicolumn{1}{|c|}{ Městská čtvrt' } & $\begin{array}{c}\text { Rozloha } \\
\text { (ha) }\end{array}$ & $\begin{array}{l}\text { Většinový } \\
\text { vlastník }\end{array}$ & \multicolumn{1}{|c|}{ Původní/současné využití } \\
\hline $\begin{array}{l}\text { BPZ-Černovická } \\
\text { terasa }\end{array}$ & $\begin{array}{l}\text { Černovice, } \\
\text { Slatina }\end{array}$ & 179,1 & město Brno & $\begin{array}{l}\text { Brownfield (vojenské letiště) i } \\
\text { greenfield, intenzivně využíváno }\end{array}$ \\
\hline Europoint Brno & $\begin{array}{l}\text { Brno-střed, } \\
\text { Brno-jih }\end{array}$ & 133,1 & $\begin{array}{l}\text { České dráhy } \\
\text { a.s. }\end{array}$ & $\begin{array}{l}\text { převažující brownfields - průmysl, } \\
\text { doprava, sklady }\end{array}$ \\
\hline $\begin{array}{l}\text { Český technologický } \\
\text { park }\end{array}$ & Královo Pole & 59,1 & město Brno & $\begin{array}{l}\text { greenfield, intenzivně využíváno, } \\
\text { část. ve výstavbě }\end{array}$ \\
\hline Areál Ponava & Královo Pole & 26,2 & město Brno & $\begin{array}{l}\text { brownfields (sport, volný čas), } \\
\text { ćástečně využiváno }\end{array}$ \\
\hline Areál Agro v Tuřanech & Tuřany & 14,5 & město Brno & $\begin{array}{l}\text { brownfields (zemědělství), částečně } \\
\text { využíváno }\end{array}$ \\
\hline Areál Hněvkovského & Brno-jih & 12,4 & město Brno & $\begin{array}{l}\text { brownfields (zemědělství), částečně } \\
\text { využíváno, část. ve výstavbě }\end{array}$ \\
\hline
\end{tabular}

Zdroj: Statutární město Brno, Kancelár primátora města Brna - Kancelář strategie města, Rozvojové lokality ortofoto mapa, 2012; vlastní zpracováni 
Průmyslová zóna Černovická terasa je strategickou zónou republikového významu a vůbec největší rozvojovou plochou v Brně. Většina zóny je obsazena, větši část je v majetku města, menší část (36 ha) byla v roce 2008 odprodána renomované developerské společnosti CTP Invest. Sídlí zde významní výrobci z oblasti zejména elektrotechniky a strojírenství (Bomar, Daikin, Daido Metal, Honeywell a další). Rozvojový projekt Europoint Brno je součástí nejkontroverznějšího a největšího projektu - výstavby nové městské čtvrti Jižního centra (více viz případová studie).

Český technologický park je prestižní středoevropskou rozvojovou zónou pro lehký hi-tech průmysl, strategické služby, výzkum a vývoj, vysokoškolské instituce i administrativu, je tedy ideálním spojení privátní a veřejné sféry. Statutární město Brno vlastní $50 \%$ akcií, $49 \%$ britská společnost Istithmar P\&O Estates, jednu prioritní akcii má Vysoké učení technické v Brně. V současné době byla dokončena I. fáze výstavby parku poskytující celkem 56,5 tis. $\mathrm{m}^{2}$ kancelářských prostor, $\mathrm{v}$ počátku budování je II. fáze, jejíž součástí je také prestižní projekt Středoevropského technologického institutu (CEITEC). V parku sídlí např. společnosti IBM, FEI, Vodafone, Motorola, Silicon Graphics a další.

Areál Ponava je nevyužívanou, resp. podvyužívanou plochou určenou zejména pro sportovní účely (fotbal, hokej - opuštěné, plavání) a zábavu a volný čas (zábavní centrum, hotel Boby), která disponuje výbornou polohou ve vnitřním městě. Projekt PPP Centra (výstavba sportovního a volnočasového areálu) byl pozastaven v roce 2010 a v současné době jsou problémem nevyřešené restituční nároky, které blokují další možnosti rozvoje areálu. Areál Agro v Tuřanech je částečně využívaný stejnojmennou společností jako operační základna pro zemědělskou výrobu, větší část leží ladem. Lokalita je zařazena do pilotního projektu města Brna který nabízí vybraná brownfields potenciálním investorům $\mathrm{k}$ revitalizaci. Areál Hněvkovského v Komárově (dř́ve s převažujícím zemědělským využitím lokality) je využíván především pro sportovní volnočasové aktivity. Plány zahrnují výstavbu multifunkčního sportovního hřiště a dosud nerozvinutá východní část areálu (podél ulice Hněvkovského), je vymezena jako víceúčelová zóna pro obchod a služby.

\section{Tab. 2: Významné developerské projekty bez majetkového podílu města Brna}

\begin{tabular}{|c|c|c|c|c|}
\hline Název & Městská čtvrt’ & $\begin{array}{l}\text { Rozloha } \\
\text { (ha) }\end{array}$ & $\begin{array}{l}\text { Většinový } \\
\text { vlastník }\end{array}$ & Původní/současné využití \\
\hline $\begin{array}{l}\text { Univerzitní Kampus } \\
\text { Bohunice }\end{array}$ & $\begin{array}{l}\text { Starý Lískovec, } \\
\text { Nový Lískovec, } \\
\text { Bohunice }\end{array}$ & 37,9 & $\begin{array}{l}\text { Masarykova } \\
\text { univerzita }\end{array}$ & intenzivně \\
\hline $\begin{array}{l}\text { Areál Zetoru - západní } \\
\text { část }\end{array}$ & Líšeň, Židenice & 28,6 & Zetor, a.s. & $\begin{array}{l}\text { brownfield (průmysl), vedlejší } \\
\text { areál využívaný }\end{array}$ \\
\hline $\begin{array}{l}\text { Bývalá Zbrojovka - } \\
\text { Zábrdovice }\end{array}$ & Židenice & 22,5 & BIANKO, s.r.o. & $\begin{array}{l}\text { brownfield (průmysl), zatím } \\
\text { pozastaveno }\end{array}$ \\
\hline Areál Slatina & Slatina & 19,5 & $\begin{array}{l}\text { Areál Slatina, } \\
\text { a.s. }\end{array}$ & $\begin{array}{l}\text { brownfields (průmysl), částečně } \\
\text { využíváno, část. ve výstavbě }\end{array}$ \\
\hline CTZone Brno & Brno-střed & 12,4 & $\begin{array}{l}\text { CTZone Brno, } \\
\text { a.s. }\end{array}$ & $\begin{array}{l}\text { brownfield (průmysl), } \\
\text { intenzivně využíváno }\end{array}$ \\
\hline Kasárna Slatina & Slatina & 9,6 & $\begin{array}{l}\text { Jižní centrum } \\
\text { Brno, a.s. }\end{array}$ & $\begin{array}{lll}\begin{array}{l}\text { brownfield } \\
\text { výstavbě }\end{array} & \text { (kasárna), ve } \\
\end{array}$ \\
\hline
\end{tabular}

Zdroj: Statutární město Brno, Kanceláŕ primátora města Brna - Kancelář strategie města, Rozvojové lokality ortofoto mapa, 2012; vlastni zpracováni

Univerzitní kampus Bohunice je rozsáhlým komplexem budov určených pro účely vzdělávání, vědu a výzkum v lékařských a přirodovědeckých oborech (nachází se zde fakulta Lékařská, Př́rodovědecká a Fakulta sportovních studií MU). Součástí komplexu jsou dílčí projekty CETOCOEN, CESEB a CEITEC, které mají mezinárodní ambice se zaměřením na vědu a výzkum. Výstavba je investována Masarykovou univerzitou $(2,2 \mathrm{mld}$. Kč), dále prostředky ze státního rozpočtu formou dotace a finanční návratné výpomoci (2,6 mld. Kč) a prostředky města Brna (300 mil. Kč). Projekt výstavby nové „městské čtvrtě“ s rezidenční, administrativní a obchodní funkcí v areálu bývalé Zbrojovky zatím nebyl realizován, je pouze v projektové př́ípravě (více viz př́padová studie). 
Západní část areálu firmy Zetor je vyhrazená pro výrobní činnosti - průmysl a smíšené využití výroby a služeb. V této opuštěné části bývalé továrny na výrobu traktorů byla provedena rozsáhlá dekontaminace. Areál Slatina je odkazem po bývalé slévárně Roučka Slatina a nabízí stabilizované plochy pro průmysl, lehkou výrobu a distribuci. V současné době se v areálu nachází 12 nájemních budov a od ledna 2013 zde probíhá výstavba administrativně-technologického parku Slatina, kterým bude rozširrena sousedící Černovická terasa. Areál bývalých Škrobáren Brno se postupně po patnáctiletém chátrání revitalizuje díky společnosti CTP Invest. Velkým problémem revitalizace byl stav technické a dopravní infrastruktury a v neposlední řadě míra ekologické zátěže. V současné době je areál, označován nyní jako CTZone Brno, využíán pro logistiku, lehkou výrobu, skladování, výzkum a vývoj a administrativu. Lokalitou protéká řeka Ponávka, jejíž koryto bylo vyčištěno a upraveno. Lokalita bývalých Kasáren Slatina je navržena pro smíšené využití v oblasti obytných prostor, obchodu a služeb, administrativy, veřejné zeleně apod. Areál je výborně dopravně obsloužen a plně vybaven inženýrskými sítěmi. Pět set nových bytů bude k dispozici zájemcům již v roce 2014, celý komplex bude dostavěn o pět let později.

V druhé části př́spěvku budou představeny tři významné developerské projekty, které mají souvislost s lokalitami brownfields. Jedná se o Europoint Brno (železniční uzel), areál bývalé Zbrojovky a deprivovanou obytnou zónu v brněnském „Bronxu“.

\section{Závěr}

Situace na stavebním trhu se za posledních několik let výrazně změnila. Absence výstavby zejména velkých infrastrukturních projektů se v posledních letech projevuje ve strategii stavebních společností, množství podaných nabídek a skladbě uchazečů o plánované projekty. Současná ekonomická krize má na svědomí zrušení nebo pozastavení mnoha plánovaných projektů, na druhou stranu je řada projektů ve výstavbě nebo se znovu rozběhla. Aktuálně převažuje výstavba luxusních nerezidenčních komplexů (administrativa, kanceláře) a novostavby v podobě bytových i rodinných domů (tzv. viladomy), a to jak na okrajích měst, tak i prrímo v jejich centru, staví se vědecké a výzkumné instituce, technologické parky, rekonstruují se architektonicky zajímavé stavby.

Pro město jsou velmi žádoucí projekty realizované na brownfields, tedy na místech nefunkčních a zchátralých průmyslových, dopravních, vojenských a dalších objektů a areálů. Ty se často „rozrůstají“ směrem k centru města a stávají se závažným problémem. Vhodným př́kladem revitalizace brownfields $\mathrm{v}$ Brně je celý komplex bývalé strojírny a slévárny Vaňkovka s dominantním nákupním centrem. Z probíhajících či plánovaných projektů nelze opomenout výstavbu Jižního centra a Europointu Brno, což je lokalita s desítkami menších brownfields, přestavbu bývalé Vlněny, Zbrojovky či slatinských kasáren na residenční a komerční prostory.

Město Brno má velký růstový potenciál vztahující se k rozvojovým lokalitám typu greenfields i brownfields. Pokud se zachová či ještě zvýší současná dynamika výstavby, do několika let se Brno stane městem překypujícím logistickými a průmyslovými areály, obchodními a nákupními komplexy, excelentními centry s řadou vědců, výzkumníků a podnikatelů. Nabízí se otázka, zda bude tato situace pro město velikosti Brna reálně udržitelná, zda se skutečně zvýší kvalita života s realizovanými projekty - v některých aspektech (obchod, kanceláře) se již trh jeví jako poměrně silně nasycený a vysoce konkurenční.

\section{Literatura}

[1] COLliER, N.S., COLliER, C.A., HALPERIN, D.A. Construction Funding: The Process of Real Estate Development, Appraisal, and Finance. New Jersey: John Wiley and Sons, 2008, $532 \mathrm{~s}$.

[2] Český ústav zeměměřičský a katastrálni [online]. [cit. 2013-05-01]. Dostupné z: $<\mathrm{http}: / /$ www.cuzk.cz/>. 
[3] DE SOUSA, C.A. Urban brownfields redevelopment in Canada: the role of local government. The Canadian Geographer, 2006, 50 (3), s. 392-407.

[4] Europoint Brno [online]. [cit. 2013-04-28]. Dostupné z: $<$ http://www.europointbrno.cz/index.php?nav01=6299>.

[5] FORAL, M., ANDRÁŠKO, I. Developerské kancelářské projekty v Brně. In Andráško, I., Dvořák, P., Ira, V. (eds) Časoprostorové změny regionálních struktur ČR a SR. Brno: Ústav geoniky AV ČR, v.v.i., 2012, s. 12-19.

[6] HRUŠKA-TVRDÝ, L., KUKULIAČ, P. Socioekonomický atlas Ostravy. Ostrava: ACCENDO - Centrum pro vědu a výzkum, o.p.s., 2011, 106 s.

[7] ILÍK, J., OUŘEDNÍČEK, M. Karlín a jeho proměny v souvislostech postsocialistické transformace Prahy. Geografie, 2007, 112 (3), s. 292-314.

[8] Integrovaný plán rozvoje města Brna [online]. [cit. 2013-05-01]. Dostupné z: $<$ http://www.iprm.brno.cz/index.php?nav01=11885>.

[9] J\&T Real Estate [online]. [cit. 2013-04-29]. Dostupné z: <http://www.jtre.sk/cs/27409.html>.

[10] Jižní centrum Brno, a.s. [online]. [cit. 2013-04-29]. Dostupné z: $<\mathrm{http} / / / \mathrm{www} . j c b r n o . c z />$.

[11] KLUSÁČEK P., KREJČ́, T., KUNC, J., MARTINÁT, S. Post-Industrial Landscape in the Relation to Local Self-Governmnet in the Czech Republic. Moravian Geographical Reports, 2011, 19 (4), s. 12-28.

[12] KLUSÁČEK, P., KREJČÍ, T., KOLEJKA, J., KUNC, J. Možnosti samosprávy a soukromých subjektů při revitalizaci brownfields. In: Nové trendy, nové nápady. Znojmo: Soukromá vysoká škola ekonomická Znojmo, 2009, s. 500-506.

[13] KREJČÍ, T., MARTINÁT, S., KLUSÁČEK, P. Spatial differentiation of the processes connected to the second demographic transition in post-socialistic cities (exampled on case of Brno and Ostrava - Czech Republic). Moravian Geographical Reports, 2011, 19 (2), s. 10-21.

[14] KUNC, J., FRANTÁL, B., KLUSÁČEK, P. (2011b): Brownfields jako lokality pro umístění obnovitelných zdrojů energie? In: Klímová, V., Žítek, V. (eds.): XIV. mezinárodní kolokvium o regionálních vědách. Sborník př́spěvkủ. Brno: Masarykova univerzita, 2011, s. 132-140.

[15] KUNC, J., KLUSÁČEK, P., MARTINÁT, S. (2011a): Percepce a lokalizace urbánních brownfields: podobnosti a rozdíly na príkladu Brna a Ostravy. Urbanismus a územní rozvoj 2011, XIV (1), s. 13-17.

[16] KUNC, J., TONEV, P. Funkční a prostorová diferenciace brownfields - př́íklad města Brna. Regionální studia, 2008, 2 (1), s. 30-37.

[17] LITT, J.S., TRAN, N.L., BURKE, T.A. Examining urban brownfields through the public health "macroscope". Environmental Health Perspect, 2001, 110 (suppl. 2), s. 183-193.

[18] Mapy.cz [online]. [cit. 2013-04-30]. Dostupné z: <http://www.mapy.cz/>.

[19] MAREŠ, J. Industrializace Československa - její klady a zápory. In Sborník Československé geografické společnosti, 93 (3), s. 183-198.

[20] MULÍČEK, O., TOUŠEK, V. Changes of Brno Industry and their Urban Consequenses. Bulletin of Geography (socio-economic series), 2004, 3, s. 61-70.

[21] Skyscraper City [online]. [cit. 2013-05-03]. Dostupné z: <http://www.skyscrapercity.com/>.

[22] Statutární mésto Brno [online]. [cit. 2013-05-03]. Dostupné z: <https://www.brno.cz/spravamesta/magistrat-mesta-brna/usek-rozvoje-mesta/kancelar-strategie-mesta/>.

[23] Stavebni fórum [online]. [cit. 2013-05-01]. Dostupné z: <http://www.stavebni-forum.cz/cs/>.

[24] STEINFÜHRER, A. The Urban Transition of Inner-City Areas Reconsidered (a German-Czech Comparison). Moravian Geographical Reports, 2006, 14 (1), s. 3-16.

[25] SÝKOROVÁ, I. Pražské brownfields: př́ležitost i hrozba pro rozvoj metropole. Geografie, 2007, 112 (3), s. 250-265.

[26] TOUŠEK, V., MULÍČEK, O. (2003): Brno - important industrial centre? Acta Universitatis Carolinae Geographica, 1, s. 437-444.

[27] VITURKA, M. Změny kvality podnikatelského prostředí podle českých krajů a správních obvodů ORP v období 2001/2002 - 2006/2008. In Žítek, V., Klímová, V. (eds.) XIV. mezinárodni kolokvium o regionálních vědách. Sborník přispěvků. Brno: Masarykova univerzita, 2011, s. 19-24.

[28] VOJVODÍKOVÁ, B. Colliery brownfields and the master plan of Ostrava. Moravian Geographical Reports, 2005, 13 (2), s. 49-56. 
[29] VOJVOdíkOVÁ, B., POTUŽNÍK, M., BÜRGERMEISTEROVÁ, R. The Database on Brownfields in Ostrava (Czech Republic): Some Approaches to Categorization. Moravian Geographical Reports, 2011, 19, 4, s. 50-60.

[30] WINKLEROVÁ, L. Transfer technologií v Jihomoravském kraji. In Klímová, V., Žítek, V. (eds.) XIV. mezinárodni kolokvium o regionálních vědách. Sborník př́spěvků. Brno: Masarykova univerzita, 2011, s. 56-63.

[31] Zbrojovka Brno [online]. [cit. 2013-05-03]. Dostupné z: <http://www.zbrojovkabrno.cz/cz/Default.aspx>.

Př́spěvek vznikl v rámci řešení projektu $7 R P$ “An Integrated Framework of Methods, Technologies, Tools and Policies for Improvement of Brownfield Regeneration in Europe" (FP7ENV-2010.3.1.5-2)

\section{Př́loha}

\section{Europoint Brno / Jižní centrum}

\begin{tabular}{lc} 
Městská část & \multicolumn{1}{c}{ Brno-střed, Brno-jih } \\
\hline Katastr & Horní Heršpice, Trnitá, Staré Brno, Město Brno, Štýřice, Komárov \\
\hline Rozloha & 133 ha \\
\hline Předchozí využití & Plochy pro dopravu, převážně brownfields částečně greenfields \\
\hline $\begin{array}{l}\text { Současné/plánované } \\
\text { s ohledem na ÚP }\end{array}$ & využití \\
\hline Investor & $\begin{array}{c}\text { Smíšené využití plochy, plochy pro dopravu a rekreaci, plochy zeleně } \\
\text { Vlastnictví }\end{array}$ \\
\hline Rok zahájení/ dokončení & $\begin{array}{c}\text { Státní fond dopravní infrastruktury, Jižní centrum Brno, a.s., Jihomoravský } \\
\text { kraj, České dráhy, a.s. , SŽDC, s.o. }\end{array}$ \\
\hline Náklady & Jižní centrum Brno, a.s., České dráhy, a.s. \\
\hline Čerpání dotací z fondů & $2006 /$ ??? \\
\hline
\end{tabular}

Rozvojový projekt Europoint Brno zahrnuje přestavbu železničního uzlu a revitalizaci a rozvoj území Jižního centra o rozloze 133 ha (pro developerskou činnost vymezeno 58,4 ha). Napojením na evropské multimodální železniční koridory by se Brno mělo stát významným mezinárodním dopravním uzlem. Uvolněné rozvojové plochy jižní části města budou využity k podnikatelským, volnočasovým i rezidenčním účelům s nabídkou nových pracovních př́ležitostí. Projekt Jižního centra, který je jedním z klíčových rozvojových projektů města Brna, je rozdělen na jednotlivá rozvojová území - Nové Sady, Trnitá, rozvojové území nádraží v odsunuté poloze a Pražákova. Do tohoto nejvýznamnějšího rozvojového území města Brna spadají lukrativní a významné dílčí developerské projekty, díky nimž stoupá atraktivita řešeného území: AZ Tower, Spielberk Office Centre, Tower B, komplex Triniti, Justiční palác, Titanium a nárožní budovy Spálená - Přízova a Nové Sady Hybešova.

Za účelem revitalizace Jižního centra vznikla v roce 1994 městská developerská společnost JIŽNÍ CENTRUM BRNO, a.s., jejímž zřizovatelem a jediným akcionářem je statutární město Brno.

\section{Historie lokality}

1839 přivedena první železniční trat' z Vídně a Břeclavi do Brna, významný objekt - 673 m dlouhý viadukt přes řeku Svratku

1845 - 1890 budovány tratě Česká Třebová - Brno, trat’ od Střelic, Přerova, Veselí nad Moravou (tzv. Vlárská trat'), Tišnova, Židenic

1904 dokončena přestavba hlavního nádraží s novými zastřešenými nástupišti, podchodem a ukončena přestavba výpravní budovy

1905 - 1976 dokončení místní dráhy Brno - Líšeň; uvedení tzv. komárovské spojky do provozu; elektrizace II. hlavního tahu Brna; stavba železniční nákladové stanice Brno-jih

1992 stanovena východiska pro přestavbu uzlu: devět variant řešení polohy nádraží

1994 zastupitelstvo Brna schválilo ÚP města s nádražím v odsunuté poloze

1997 - 1998 podrobná dopravně-urbanistická studie potvrzuje odsunutou polohu nádraží 
2002 vláda schvaluje přestavbu uzlu s nádražím v odsunuté poloze

2003 - 2005 zpracování odborných studií k přestavbě uzlu včetně studie EIA

2004 referendum o poloze nádraží 9. ř́jna 2004 nebylo pro nízkou účast voličů $(27,9$ \%) závazné

2006 stavební úřad vydal územní rozhodnutí o přestavbě uzlu

2007-2010 vybudování 1. části odstavného nádraží, úvodu pro přestavbu brněnského uzlu

2008 projekční práce na dokumentacích pro stavební povolení, soud zrušil územní rozhodnutí o přestavbě uzlu a vrátil jej k novému projednání

2010 stavební úřad vydává nové územní rozhodnutí o přestavbě uzlu - není pravomocné; v záŕí 2010 vláda schválila rozpočet SFDI pro rok 2011, v němž nebyla přstavba uzlu zahrnuta (projekční práce pokračují)

\section{Současné využití}

Modernizace železničního uzlu je součástí intenzivního úsilí města Brna o dynamický rozvoj ve prospěch svých obyvatel, ale problémem stále zůstává neexistence územního rozhodnutí pro rozhodující část přestavby a s ním spojeného stavebního povolení. Na rozvojové území Nové Sady (bývalé uhelné sklady a skladové areály) je plánována výstavba rezidenčních i nerezidenčních objektů (podnikání, veřejná správa, služby) podporující zkvalitnění občanské vybavenosti. Rozvojové území Trnitá sousedí s Galerií Vaňkovka, která se stala vstupní „branou“ Jižního centra. Lokalita, nabízející uskutečnění variant podnikatelských záměrů, je také určena pro kvalitní a atraktivní bydlení, kulturu a hospodářský rozvoj města. Stěžejní záležitostí je rozvojové území „nového nádraží“ (vybudování vlakového nádraží v těsném sousedství autobusového nádraží), které pak bude nabízet sociálně-kulturní př́ležitosti a podnikatelsko-ekonomické výhody. Rozvojové území Pražákova je plánováno pro rozvoj služeb, sportu a volnočasových aktivit, stravování, maloobchodu a drobné výroby. Nově se zde staví komplex s označením H-Park (projekt komerčních ploch o celkové podlažní ploše $8000 \mathrm{~m}^{2}$, developer Raiffeisen - Leasing, s.r.o.).

Obdobné projekty přestavby železničních uzlů probíhají i v partnerských městech Brna, např. ve Vídni funguje od prosince 2012 částečný provoz nového nádraží Vídeň-střed, jehož dokončení je plánováno na rok 2015 (přestavba doposud trvala 24 let). ${ }^{1}$

\section{Obr. 1: Europoint Brno / Jižní Centru}

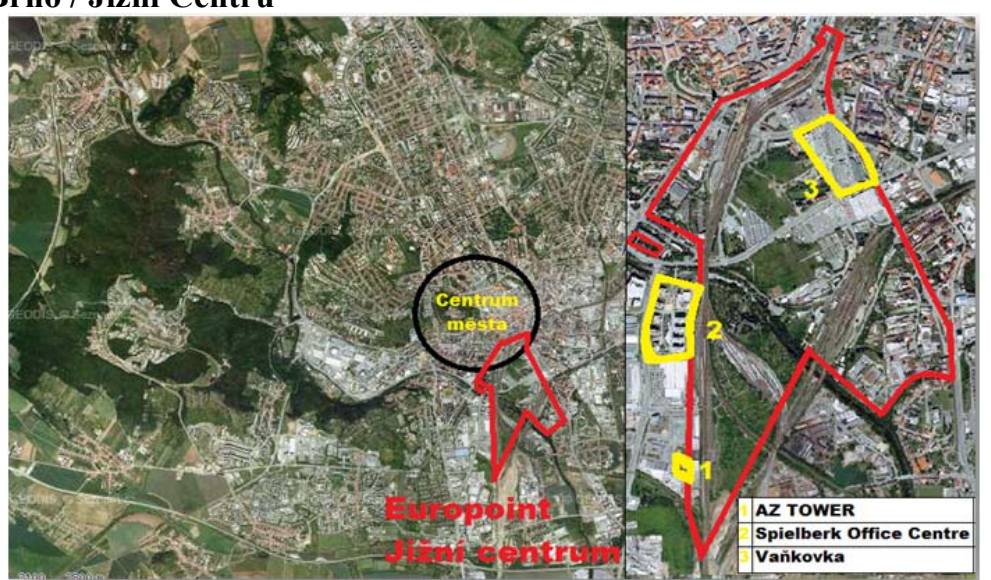

Zdroj: Mapy.cz ( http://mapy.cz/\# $x=16.660076 \& y=49.188849 \& z=11 \& l=15 \& c=2-3-8-15-25-H)$, ,, (C) GEODIS BRNO, s.r.o", vlastní zpracování

\footnotetext{
${ }^{1}$ Zdroj: Europoint Brno (http://www.europointbrno.cz) a Jižní centrum Brno (http://www.jcbrno.cz)
} 
Obr. 2: Pozemky a vlastnictví pozemků v rozvojové lokalitě Jižního centra města Brna

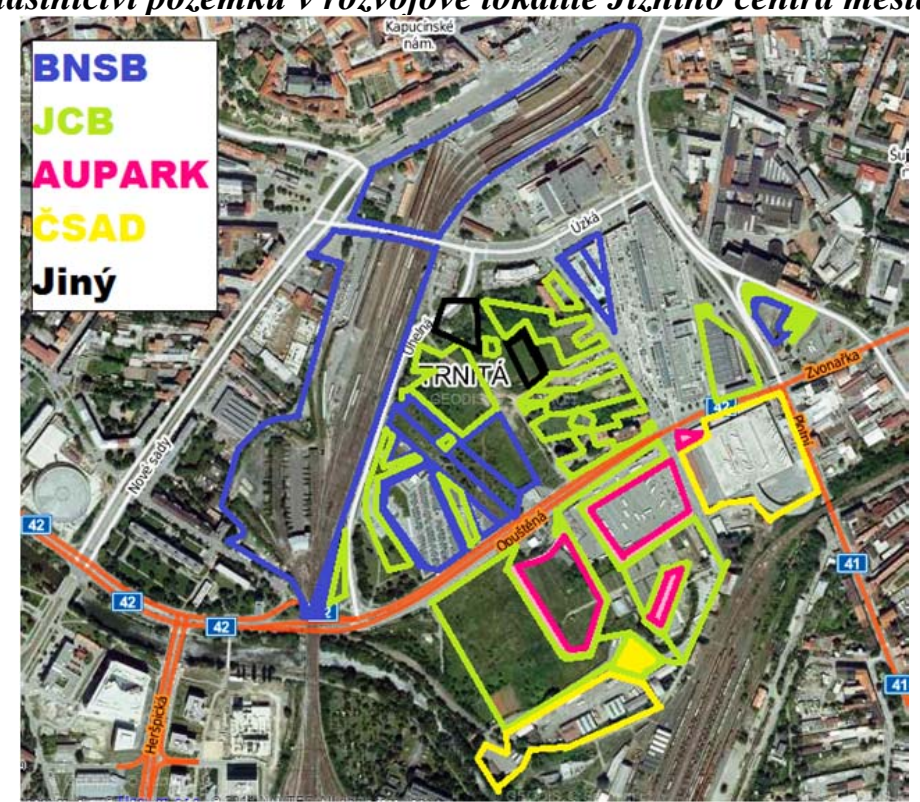

Zdroj: Mapy.cz (http://mapy.cz/\#x=16.660076\&y=49.188849\&z=11\&l=15\&c=2-3-8-15-25-H), ,, (C) GEODIS BRNO, s.r.o", vyznačené pozemky jsou zakresleny na základè katastru nemovitostí:

(http://nahlizenidokn.cuzk.cz), vlastní zpracování

BNSB Brno New Station Development, a.s.; Karlín Development, s.r.o.; Randora, a.s.; Vodička, a.s.; AXA penzijní fond, a.s.; Dominikánská, s.r.o.

JCB Jižní centrum Brno, a.s.

AUPARK AUPARK Brno, s.r.o.

ČSAD ČSAD Brno Holding, a.s.

Jiný Magdalena Janottová - restituentka; Domácí potřeby Brno - v likvidaci Deprivovaná obytná zóna Bratislavská, Cejl, Francouzská, Přádlácká, Hvězdová,
Spolková, Soudní

\begin{tabular}{lc}
\hline Městská část & Brno-střed, Brno-sever \\
\hline Katastr & Zábrdovice \\
\hline Rozloha & 19,5 ha \\
\hline Předchozí využití & Bydlení, služby, brownfield \\
\hline Současné/plánované využití s ohledem na ÚP & Residenční oblast, bydlení, výroba, služby \\
\hline Investor & Město Brno, soukromí investoři \\
\hline Vlastnictví & Město Brno $32 \%$ \\
\hline Rok zahájení/ dokončení & $2008 / 2015$ \\
\hline Náklady & 450 mil. Kč \\
\hline Čerpání dotací z fondů & Ano
\end{tabular}

Problémová lokalita Zábrdovic, nazývána také brněnský „Bronx“, je charakteristická neudržovanými objekty bez zeleně a veřejných prostranství a delší dobu se potýká s problémy dlouhodobé nezaměstnanosti, nízké úrovně vzdělanosti a nízké ekonomické aktivity. V roce 2008 město Brno zahájilo př́pravu projektu „Integrovaného plánu rozvoje města Brna v problémové obytné zóně města“, na který získalo dotace z Evropského fondu regionálního rozvoje ve výši 134 mil. Kč. Na projektu revitalizace lokality spolupracují př́slušné odbory MMB s městskými částmi Brno-sever a Brno-střed a také soukromí vlastníci bytových domů. V rámci IPRM jsou podporovány aktivity - revitalizace veřejných prostranství (dotace $85 \%$ ), regenerace bytového fondu (dotace 40-60 \%) a pilotní projekt regenerace bytového fondu (dotace 40-60 \%).

\section{Historie lokality}

18. století dělnické předměstí s prvními textilními manufakturami, výstavba klasicistních domů pro ubytování dělníků, na přelomu 18. a 19. století začala výstavba pavlačových činžovních domů 


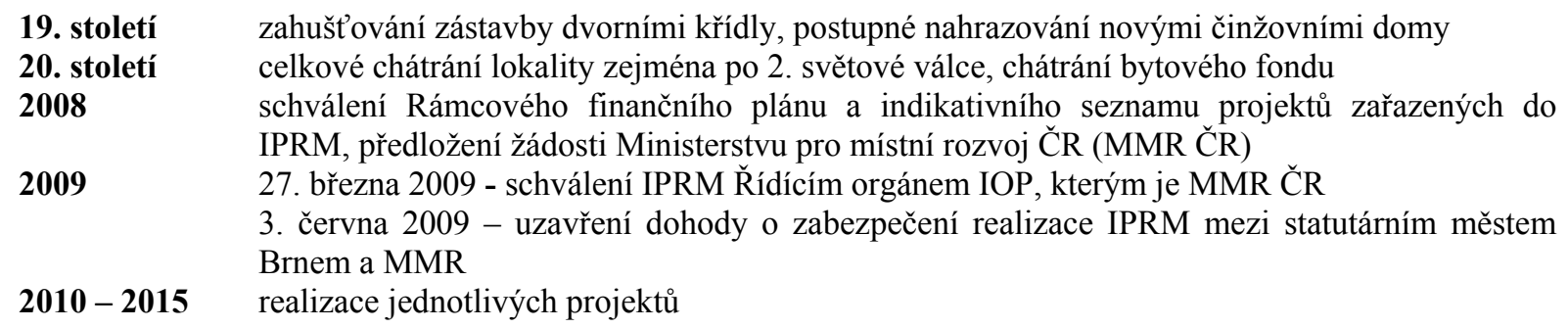

\section{Současné využití}

Regenerace bytového fondu je finančně i časově náročná aktivita. Realizace prripravených projektů by měla výrazně zlepšit stav bytového fondu a veřejného prostranství v dané lokalitě. Dlouhodobým cílem a záměrem města Brna je vymizení sociálně vyloučené lokality, navrácení její ztracené úrovně a zatraktivnění pro bydlení a volný čas. V revitalizované oblasti bude patrně „,vlajkovou lodi““ samostatný projekt Kreativní centrum Brno, které podporuje začínající podnikatele v kreativních průmyslech (inkubátory), poskytuje prostory pro volné umění (nájemní ateliéry) a kulturně-vzdělávací aktivity pro širokou veřejnost. Aktivity projektu, které jsou iniciativou Kanceláře strategie města Brna a jsou podporované Evropskými fondy, budou mít své centrum na Bratislavské 68 (objekt bývalé káznice). ${ }^{2}$ Od července 2013 by zde měly být otevřeny první zkušební prostory pro začínající i etablované umělce.

\section{Obr. 3. Deprivovaná obytná zóna}

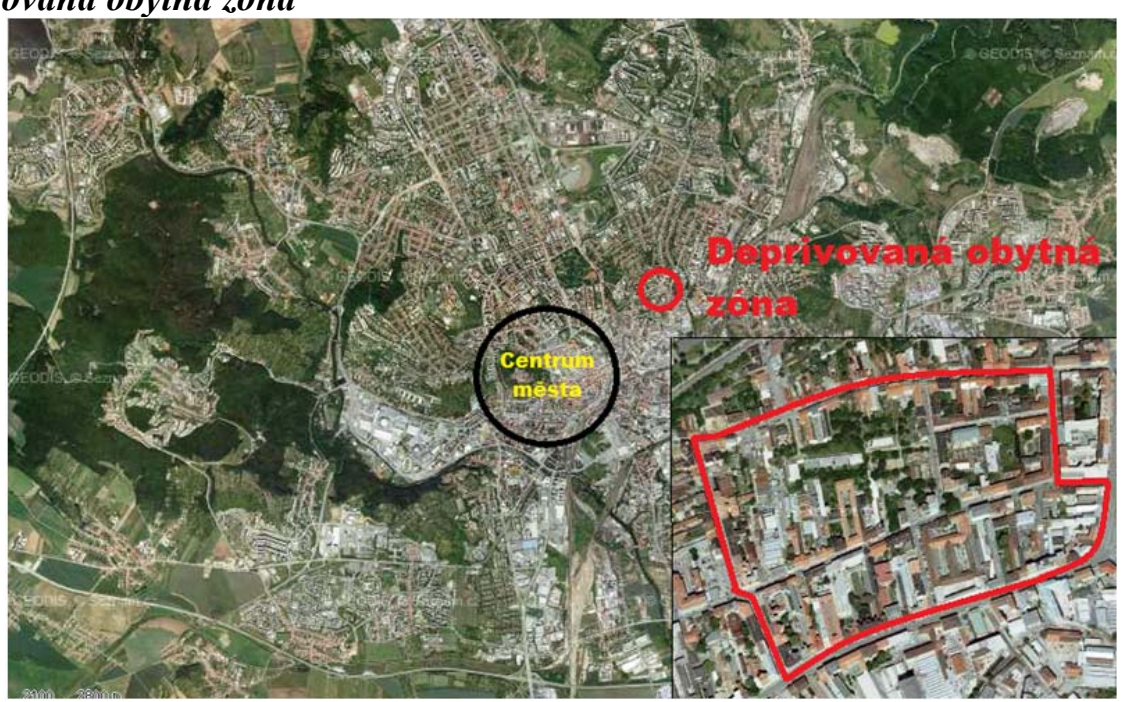

Zdroj: Mapy.cz (http://mapy.cz/\#x=16.616535\&y=49.187388\&z=15\&l=15\&c=2-3-8-15-25-H), ,, C GEODIS BRNO, s.r.o“, vlastní zpracování

\footnotetext{
${ }^{2}$ Zdroj: Integrovaný plán rozvoje města Brna( http://www.iprm.brno.cz/index.php?nav01=11885), Brownfields 2013, vydalo Statutární město Brno, 2013, s.56-57, s.60, Integrovaný plán rozvoje města v problémové obytné zóně 2008-2015, vydalo Statutární město Brno, 2012, s. 66
} 


\section{Obr. 4: Ulice Bratislavská a Cejl}

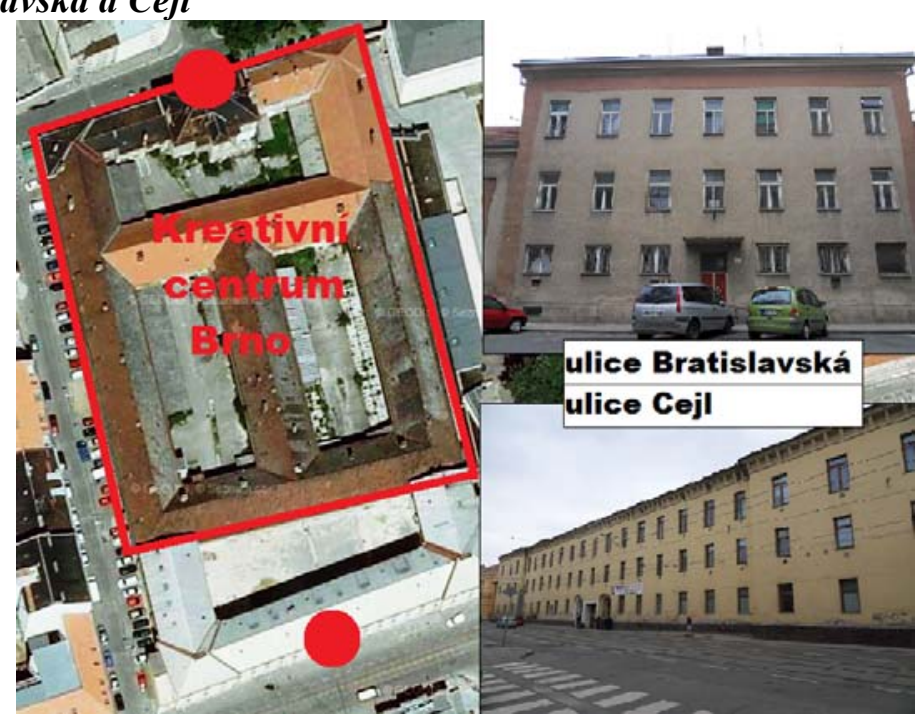

Zdroj: Mapy.cz (http://mapy.cz/\#x=16.616535\&y=49.187388\&z=15\&l=15\&c=2-3-8-15-25-H), , (C GEODIS BRNO, s.r.o“, vlastni foto a zpracování

\section{Bývalá Zbrojovka - Zábrdovice}

\begin{tabular}{|c|c|}
\hline Městská část & Brno-Židenice \\
\hline Katastr & Zábrdovice \\
\hline Rozloha & 22,5 ha \\
\hline Předchozí využití & Brownfield \\
\hline $\begin{array}{l}\text { Současné/plánované } \\
\text { s ohledem na ÚP }\end{array}$ & $\begin{array}{c}\text { Nová městská čtvrt', residenční i nerezidenční prostory, obchod, } \\
\text { služby }\end{array}$ \\
\hline Investor & Společnost J\&T Real Estate, Czech Property Investments \\
\hline Vlastnictví & $\begin{array}{c}\text { BIANKO, s.r.o., společnost J\&T Real Estate, Brno Rifles, s.r.o., } \\
\text { Czech Property Investments }\end{array}$ \\
\hline Rok zahájení/ dokončení & $2011 / ? ? ?$ \\
\hline Náklady & $11 \mathrm{mld} . \mathrm{Kč}$ \\
\hline Čerpání dotací z fondů & $\mathrm{Ne}$ \\
\hline
\end{tabular}

Československá státní zbrojovka byla v Brně založena roku 1918 se záměrem opravovat automobily, pušky, telefonní a železniční zařízení a nářadí. V době své největší slávy (ve 30. letech) vyráběla licenční psací stroje Remington a traktory Škoda a měla po celém světě přes 70 továren. V 80. letech se pak společnost začíná přeorientovávat na komunikační a výpočetní technologie a techniku. V roce 2008 vydražila areál Zbrojovny Brno společnost $J \& T$, která patří $\mathrm{k}$ největším finančním skupinám působících v ČR. Společnost J\&T má $\mathrm{s}$ areálem stejný záměr jako v pražském Karlíně (srovnala se zemí historický areál Prvních pražských strojíren Rustonky). Výstavbu „nové čtvrtě“ plánuje společnost na několik desítek let, přičemž odstranění staré ekologické zátěže, podzemní vody, vytvoření projektové dokumentace, změna územního plánu a v neposlední řadě nastupující krize v roce 2008 - to vše zatím zabrzdilo zahájení realizace projektu na neurčito.

\section{Historie lokality}

1870 výstavby nejstarší budovy v areálu

1918 založení společnosti Zbrojovka Brno

1924 postavena nová továrna, kde se stavěly pušky, kulomety, vyráběly automobily, motory, opravovaly vagony, železniční nářadí atd., Zbrojovka se stala $v 2$. Polovině 20 . let jedním z největších výrobců pušek na světě

1934-1938 Zbrojovka se stává koncernem světového významu

1944 továrna silně poškozena bombardováním

1945 vyroben prototyp traktoru Zetor Z-25

1950-1990 vyráběna kancelářská a sdělovací technika, dieslové motory, nářadí, lovecké a sportovní zbraně

2003 společnost začíná krachovat, vyhlášení konkurzu 
2006 ukončena výroba zbraní (srpen), vydražení obráběcího centra a část dalšího strojového zařízení Zbrojovky Brno společností Brno Rifles

2007 vyexpedování první kozlice společností Brno Rifles, dražba výrobního areálu Zbrojovky Brno

2008 areál Zbrojovky Brno vydražen za rekordní částku 707 mil. Kč (společnost J\&T)

2009 přesídlení společnosti Brno Rifles $\mathrm{z}$ areálu bývalé brněnské zbrojovky do nedalekého učňovského střediska

2010 majitel České zbrojovky Uherský Brod získal ochranné známky a znak zaniklé Zbrojovky Brno, vzápětí ale došlo k př́ejmenování Brno Rifles na na Zbrojovku Brno, s.r.o.

\section{Současné využití}

V současné době je areál využiván několika společnostmi. Areál je využíván $\mathrm{k}$ fotografickým pracím, prostory jsou využívány jako hudební zkušebny a konají se zde např. i festivaly (Burning Factory Beats Party v roce 2010) a party (Bassinfestion v roce 2011). V původním průmyslovém areálu Zbrojovky by měla vzniknout nová Zbrojovka, obytná městská čtvrt's byty, obchody a kancelářemi. ${ }^{3}$

\section{Obr. 5: Bývalá Zbrojovka}

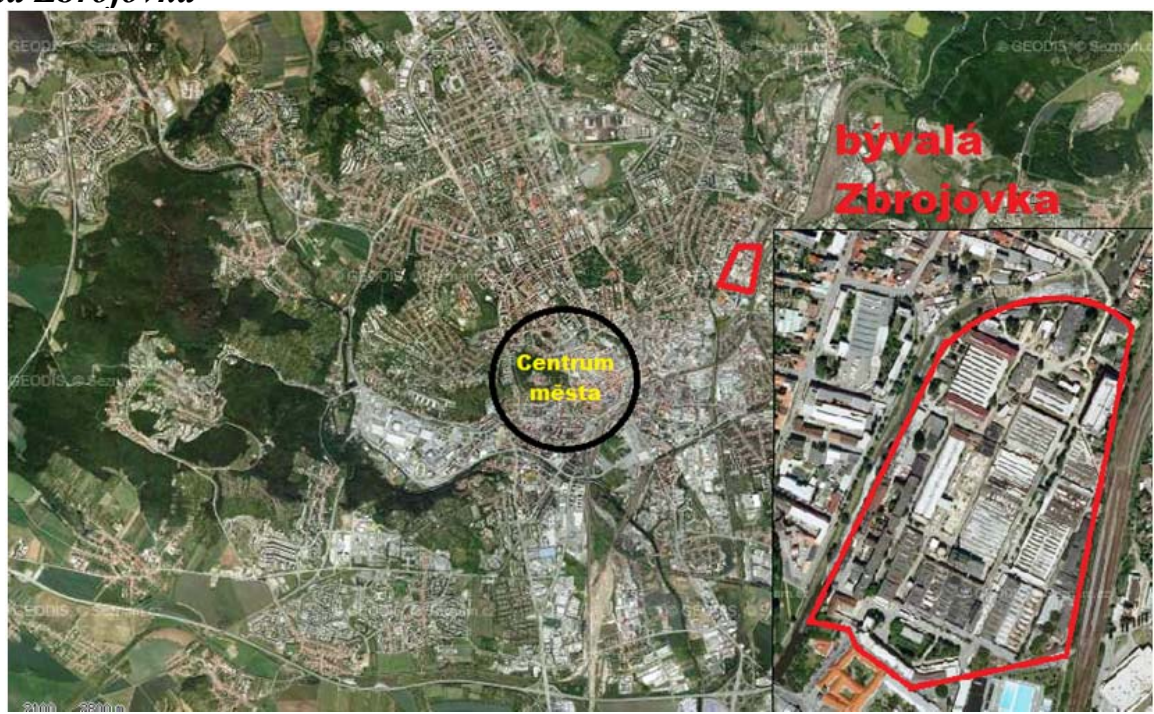

Zdroj: Mapy.cz (http://mapy.cz/\#x=16.616535\&y=49.187388\&z=15\&l=15\&c=2-3-8-15-25-H), ,, (C) GEODIS BRNO, s.r.o“, vlastní zpracování

Obr. 6: Areál bývalé Zbrojovky

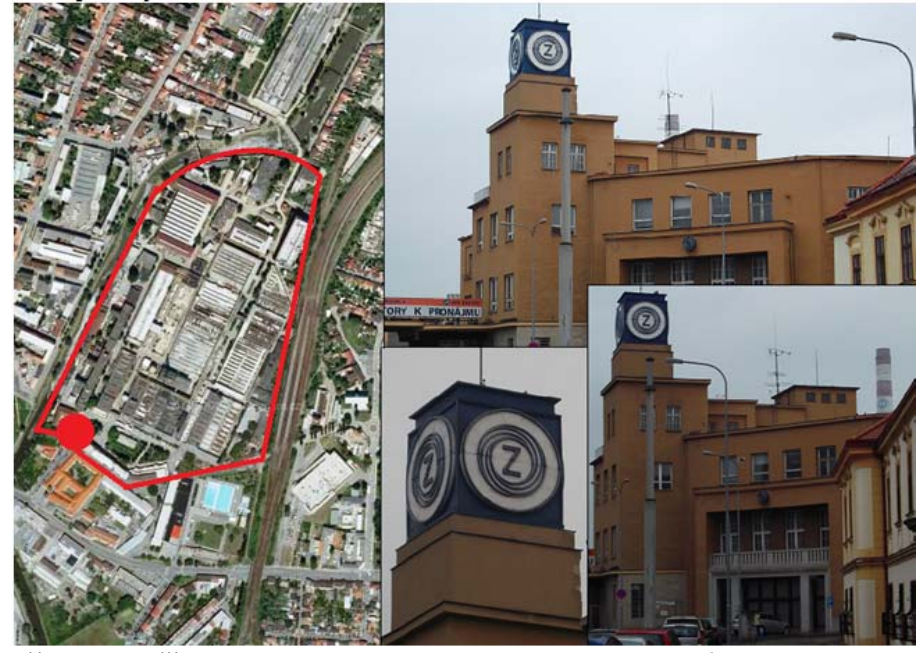

Zdroj: Mapy.cz (http://mapy.cz/\#x=16.616535\&y=49.187388\&z=15\&l=15\&c=2-3-8-15-25-H), , (C GEODIS BRNO, s.r.o", vlastní foto a zpracování

\footnotetext{
3 Zdroj: Zbrojovka Brno (http://www.zbrojovka-brno.cz/cz/Default.aspx), J\&T $\quad$ Real $\quad$ Estate (http://www.jtre.sk/cs/27409.html), Stavební fórum (http://www.stavebni-forum.cz/cs/article/21920/brno-projekt-zbrojovkase-odklada), Skyscraper City (http://www.skyscrapercity.com/showthread.php?t=1114605)
} 